\title{
ANALISIS DAYA SAING UBI KAYU INDONESIA DI PASAR INTERNASIONAL
}

\author{
Fahrisa Surya Pramesti ${ }^{1)}$, Endang Siti Rahayu ${ }^{2)}$, Agustono $^{3)}$ \\ 1) Mahasiswa Program Studi Agribisnis Fakultas Pertanian, UNS. \\ 2) Dosen Pembimbing Utama \\ 3) Dosen Pembimbing Pendamping \\ Program Studi Agribisnis Fakultas Pertanian, Universitas Sebelas Maret Surakarta \\ J1. Ir. Sutami No. 36A Kentingan Surakarta 57126 Telp/Fax. (0271) 637457 \\ Email: suryafahris@gmail.com
}

\begin{abstract}
This research aims to determine the competitiveness of cassava Indonesia compared with competitor countries if the terms of its comparative advantages, and to know the competitiveness of Indonesian cassava if the terms of its competitive advantage. The basic method used is descriptive analytical method. Analysis of the data used is the analysis of comparative advantage Revealed Comparative Advantage (RCA) and analysis of competitive advantage Privat Cost Ratio (PCR). RCA analysis results for commodities cassava Indonesia has a value of 0.7 or below one, which means that during the period of cassava Indonesia does not have a comparative advantage compared to other countries with the same commodity. While the results of PCR analysis, farming cassava in Indonesia has a competitive advantage because it has a PCR value of 0.36 or less than one, which means that to get the added value of farm output by one unit cassava required additional domestic factor costs less than one unit is equal to 0,36 . While private profits is positive, it shows that the indication of the results of farming cassava Indonesia supernormal and should lead to the expansion or expansion in the future, unless the agricultural areas in Indonesia can not be expanded or substitute crops are more profitable in private.
\end{abstract}

Keywords : cassava, export, competitiveness, competitive, comparative

\begin{abstract}
Abstrak: Penelitian ini bertujuan untuk mengetahui daya saing ubi kayu Indonesia dibandingkan dengan negara pesaing jika ditinjau dari keunggulan komparatifnya, dan mengetahui daya saing ubi kayu Indonesia jika ditinjau dari keunggulan kompetitifnya. Metode dasar yang digunakan adalah metode deskriptif analitis. Analisis data yang digunakan adalah analisis keunggulan komparatif Revealed Comparative Advantage (RCA) dan analisis keunggulan kompetitif Privat Cost Ratio (PCR). Hasil analisis RCA untuk komoditas ubi kayu Indonesia memiliki nilai 0,7 atau di bawah satu, yang berarti pada periode tersebut ubi kayu Indonesia tidak memiliki keunggulan komparatif dibandingkan dengan negara lain dengan komoditas yang sama. Sedangkan hasil analisis PCR, usahatani ubi kayu di Indonesia memiliki keunggulan kompetitif karena memiliki nilai PCR 0,36 atau kurang dari satu, yang berarti untuk mendapatkan nilai tambah output usahatani ubi kayu sebesar satu satuan diperlukan tambahan biaya faktor domestik kurang dari satu satuan yaitu sebesar 0,36. Sedangkan keuntungan privat bernilai positif, hal tersebut menunjukkan bahwa indikasi dari hasil usahatani ubi kayu Indonesia supernormal dan harus mengarah pada ekspansi atau perluasan di masa mendatang, kecuali apabila daerah pertanian di Indonesia tidak dapat diperluas atau terdapat tanaman pengganti yang lebih menguntungkan secara privat.
\end{abstract}

Kata kunci : ubi kayu, ekspor, daya saing, kompetitif, komparatif 


\section{PENDAHULUAN}

Sektor pertanian terdiri dari beberapa subsektor. Salah satu subsektor yang memberi kontribusi penting adalah tanaman pangan karena perannya dalam mencapai swasembada pangan melalui program diversifikasi pangan. Kontribusi nominal Produk Domestik Bruto (PDB) dari tanaman bahan makanan merupakan kontribusi terbesar PDB sektor pertanian. Nilai tanaman pangan selalu mengalami peningkatan dari tahun ke tahun, rata-rata peningkatan nilai tanaman pangan setiap tahunnya sebesar 16,08\% (BPS, 2015).

Salah satu komoditas tanaman pangan yang menjadi unggulan dan mempunyai potensi dalam pertumbuhan ekonomi Indonesia adalah ubi kayu. Indonesia merupakan salah satu produsen dan eksportir utama ubi kayu di dunia. Indonesia termasuk dalam lima besar negara produsen ubi kayu selama tahun 2004 hingga data terakhir tahun 2013 (FAO, 2015). Indonesia masih memiliki peluang untuk meningkatkan ekspor. Potensi produksi ubi kayu Indonesia didukung oleh produktivitas ubi kayu yang selalu positif dan meningkat walaupun produksi dan luas lahan mengalami fluktuasi (Tabel 1).

Perdagangan ubi kayu saat ini semakin berkembang yang ditandai dengan semakin meningkatnya permintaan ubi kayu oleh negara-negara konsumen dan semakin banyaknya jumlah negara pengekspor ubi kayu di dunia.. China merupakan negara konsumen terbesar ubi kayu di dunia selama periode
2004-2013. Selain itu, negara pengimpor ubi kayu utama lainnya adalah Korea Selatan, Thailand, Amerika Serikat, Jepang, Filipina, Brazil, dan Belanda. Sementara itu, negara pengekspor utama ubi kayu selain Indonesia antara lain Thailand, Vietnam, Costa Rica, Kamboja, Paraguay, Uganda, Belanda, Nikaragua, dain Srilanka (FAO, 2015).

Berdasarkan potensi dan kemampuan yang dimiliki, Indonesia sebenarnya mampu menghadapi persaingan yang semakin ketat di pasar internasional terutama dalam menghadapi liberalisasi perdagangan dimana tidak ada hambatan dalam perdagangan, namun hal tersebut harus diikuti dengan adanya mutu dan kualitas yang baik pada komoditi yang diperdagangkan sehingga dapat berperan penting dalam perdagangan internasional. Potensi yang cukup besar tersebut dapat menentukan keunggulan dan kemampuan yang dimiliki komoditi ubi kayu Indonesia dalam menghadapi liberalisasi perdagangan. Oleh karena itu, penelitian mengenai daya saing ubi kayu Indonesia perlu dilakukan untuk mengetahui posisi bersaing Indonesia dalam perdagangan komoditi ubi kayu di pasar internasional.

\section{METODE PENELITIAN}

Metode dasar yang digunakan dalam penelitian ini adalah metode deskriptif analitis yaitu metode penelitian dengan membahas suatu permasalahan dengan cara meneliti, menguraikan, menganalisis dan

Tabel 1. Luas Panen, Produktivitas, dan Produksi Tanaman Ubi Kayu di Indonesia Tahun 2004-2013

\begin{tabular}{cccc}
\hline Tahun & Luas Panen (ha) & Produktivitas $(\mathrm{kw} / \mathrm{ha})$ & Produksi (ton) \\
\hline 2004 & 1.255 .805 & 155.00 & 19.424 .707 \\
2005 & 1.213 .460 & 159.00 & 19.321 .183 \\
2006 & 1.227 .459 & 163.00 & 19.986 .640 \\
2007 & 1.201 .481 & 166.36 & 19.988 .058 \\
2008 & 1.204 .933 & 180.57 & 21.756 .991 \\
2009 & 1.175 .666 & 187.46 & 22.039 .145 \\
2010 & 1.183 .047 & 202.17 & 23.918 .118 \\
2011 & 1.184 .696 & 202.96 & 24.044 .025 \\
2012 & 1.129 .688 & 214.02 & 24.177 .372 \\
2013 & 1.065 .752 & 224.60 & 23.936 .921 \\
\hline
\end{tabular}

Sumber: BPS 2015 
menginterpretasikan hal-hal yang ditulis dengan pembahasan yang teratur dan sistematis (Arifin dan Junaiyah, 2010).

Data yang digunakan dalam penelitian ini adalah data sekunder pada tahun 2013.

\section{Revealed Comparative Advantage (RCA)}

Metode RCA didasarkan pada suatu konsep bahwa perdagangan antar wilayah sebenarnya menunjukkan keunggulan komparatif yang dimiliki oleh suatu wilayah (Anwar, 2014)

Untuk menganalisis keunggulan komparatif dari komoditas tertentu di suatu Negara dapat menggunakan RCA (Revealed Comparative Advantage) yang bertujuan untuk membandingkan pangsa pasar ekspor sektor tertentu suatu Negara dengan pangsa pasar sektor tertentu negara atau produsen lainnnya serta menunjukkan daya saing industri suatu Negara. Formula RCA dirumuskan sebagai berikut:

$$
R C A=\frac{X i j / \Sigma i X i j}{\Sigma j \mathrm{Xij} / \Sigma \mathrm{i} \Sigma \mathrm{j} \mathrm{Xij}}
$$

Dimana : Xij adalah nilai ekspor komoditas ubi kayu negara Indonesia, $\Sigma \mathrm{i}$ Xij adalah total nilai ekspor seluruh komoditas pertanian dari negara Indonesia, $\Sigma \mathrm{j} \mathrm{Xij}$ adalah total nilai ekspor dunia dari komoditas ubi kayu, $\Sigma \mathrm{i} \Sigma \mathrm{j} \mathrm{Xij}$ adalah total nilai ekspor dunia untuk seluruh komoditas pertanian, semakin tinggi nilai RCA maka daya saing suatu negara akan semakin kuat (Basri, 2010).

\section{Privat Cost Ratio (PCR)}

Rasio biaya privat (Private Cost Ratio) merupakan rasio antara biaya privat input non tradable dengan selisih antara penerimaan privat dengan biaya privat input tradable privat. Nilai Privat Cost Ratio (PCR) menunjukkan kemampuan sistem untuk membayar biaya domestik pada harga privat atau aktualnya. Rasio biaya privat (PCR) dirumuskan sebagai berikut:

$$
\mathbf{P C R}=\mathrm{C} /(\mathrm{A}-\mathrm{B})
$$

Dimana

$$
\begin{array}{ll}
\text { PCR } & \text { : Privat Cost Ratio } \\
\text { A } & \text { : Penerimaan Privat } \\
\text { B } & \text { : Biaya input Tradable Privat } \\
\text { C } & \text { : Biaya input non tradable Privat }
\end{array}
$$

Apabila:

Privat Cost Ratio (PCR) < 1, berarti sistem komoditas tersebut mampu membiayai faktor domestiknya pada harga privat, dengan kata lain komoditas tersebut memiliki keunggulan kompetitif. Semakin kecil nilai Privat Cost Ratio (PCR) berarti komoditas tersebut semakin kompetitif.

Privat Cost Ratio (PCR) > 1, berarti sistem komoditas tersebut tidak mampu membiayai faktor domestiknya pada harga privat, dengan kata lain komoditas tersebut tidak memiliki keunggulan kompetitif. (Monke dan Pearson, 1989)

\section{HASIL DAN PEMBAHASAN}

\section{Keragaan Ubi Kayu Indonesia}

Ubi kayu merupakan salah satu bahan pangan pengganti beras yang cukup penting peranaannya dalam menopang ketahanan pangan suatu wilayah. Disamping sebagai bahan makanan, ubi kayu juga dapat digunakan sebagai bahan baku industri dan pakan ternak. Ubi yang dihasilkan mengandung air sekitar $60 \%$, pati $25 \%-35 \%$, serta protein, mineral, serat, kalsium, dan fosfat (Widianta 2008 dalam Outlook Ubi Kayu 2011). Berdasarkan data BPS (2016) dapat diketahui bahwa selama lima tahun terakhir, Provinsi Lampung memiliki total produksi paling besar di Indonesia dengan besar 7.387.084 ton yang diikuti dengan Provinsi Jawa Tengah, Jawa Timur, Jawa Barat, dan Sumatera Utara. Provinsi Lampung juga memiliki luas panen yang paling tinggi sebesar 279.337 hektar. Sedangkan produktivitas tertinggi dimiliki Provinsi Sumatera Utara yaitu sebesar 338,54 kwintal per hektar.

Terjadi peningkatan demand yang cukup baik dimanfaatkan sebagai tambahan pendapatan negara. Berdasarkan kecenderungan ekspor dan impor produk ubi kayu selama periode 2004-2013, pasar dunia untuk produk ubi kayu kering relatif meningkat setiap tahun. Peningkatan tersebut dikarenakan semakin banyaknya negara importir ubi kayu yang produksi dalam negerinya tidak dapat mencukupi permintaan dalam negeri (FAO, 2015). Melihat potensi produksi dan permintaan yang semakin positif, dapat digambarkan bahwa komoditi ubi kayu 
Fahrisa Surya P., Endang Siti R., Agustono : Analisis Daya Saing Ubi Kayu...

Tabel 2. Perhitungan Nilai RCA Komoditas Ubi Kayu Indonesia tahun 2013

\begin{tabular}{lrrr}
\hline \multicolumn{1}{c}{ Negara } & $\begin{array}{c}\text { Nilai Ekspor Komoditi Ubi } \\
\text { Kayu (1000 US\$) }\end{array}$ & $\begin{array}{c}\text { Total Ekspor Komoditas } \\
\text { Pertanian (1000 US\$) }\end{array}$ & Nilai RCA \\
\hline Thailand & 1.317 .646 & 30.877 .359 & 32,63140094 \\
Vietnam & 363.710 & 10.100 .320 & 27,53577011 \\
Indonesia & 32.111 & 34.873 .537 & 0,704100985 \\
Belanda & 13.476 & 90.945 .022 & 0,113307639 \\
\hline Dunia & 1.827 .009 & 1.397 .068 .837 & \\
\hline
\end{tabular}

Sumber: Data Penelitian yang diolah, 2016.

merupakan salah satu komoditi tanaman potensial untuk menggerakkan perekonomian Indonesia melalui sektor pertanian tanaman pangan. Dukungan potensi Indonesia dapat menjadikan Indonesia sebagai salah satu produsen ubi kayu dunia, juga dapat menjadikan ubi kayu sebagai salah satu sumber devisa yang patut dikembangkan.

\section{Analisis Keunggulan Komparatif Ubi Kayu Indonesia}

Revealed Comparative Advantage (RCA) adalah salah satu metode yang dapat digunakan untuk mengetahui daya saing suatu wilayah negara, provinsi, dan lain-lain. Revealed Comparative Advantage (RCA) pada dasarnya digunakan untuk menentukan posisi ekspor suatu komoditi negara tertentu terhadap negara lainnya. RCA juga merupakan indeks untuk menghitung keuntungan dan kerugian relatif suatu komoditas pada suatu negara yang berdasarkan pola perdagangannya. Metode RCA didasarkan pada suatu konsep bahwa perdagangan antar wilayah sebenarnya menunjukkan keunggulan komparatif yang dimiliki oleh suatu wilayah. Variabel yang diukur adalah kinerja ekspor suatu produk/komoditas terhadap total ekspor suatu daerah yang kemudian dibandingkan dengan pangsa nilai produk dalam perdagangan di suatu negara.

Berdasarkan data ekspor ubi kayu Indonesia dan ekspor ubi kayu dunia periode 2013 yang diperoleh dari beberapa instansi terkait, didapatkan variabel nilai ekspor ubi kayu Indonesia, nilai total ekspor komoditas pertanian Indonesia, nilai ekspor ubi kayu dunia, dan nilai total ekspor komoditas pertanian di dunia. Dari variabel-variabel tersebut dapat diolah untuk mendapatkan variabel daya saing melalui metode RCA.
Perhitungan RCA secara lengkap terdapat di halaman lampiran, sedangkan hasil perhitungan RCA dapat dilihat pada Tabel 2.

Apabila diperhatikan pada Tabel 2, dalam periode tahun 2013, terlihat bahwa nilai Revealed Comparative Advantage (RCA) untuk komoditas ubi kayu Indonesia memiliki nilai 0,7 atau di bawah satu, yang berarti pada periode tersebut ubi kayu Indonesia tidak memiliki keunggulan komparatif dibandingkan dengan negara lain dengan komoditas yang sama. Nilai Revealed Comparative Advantage (RCA) yang rendah tersebut dapat terjadi karena beberapa hal misalnya pengaruh kebutuhan ubi kayu kering untuk industri dalam negeri yang semakin besar sehingga produksi ubi kayu diutamakan untuk pemenuhan kebutuhan ubi kayu kering di dalam negeri daripada untuk ekspor, atau industri tepung ubi kayu kering dalam negeri yang tidak berkembang, tidak efisien, atau tidak menarik bagi investor untuk bergerak dalam industri agro karena keuntungan yang diperoleh kecil. Akan tetapi nilai tersebut mengalami peningkatan apabila dibandingkan dari tahun sebelumnya yaitu sebesar 0,22 pada tahun 2012 dan 0,64 pada tahun 2011. Hal ini dapat terjadi karena permintaan ubi kayu luar negeri yang juga meningkat sebagai bahan baku bioetanol serta membaiknya harga di tingkat petani dan harga rata-rata ubi kayu di pasar internasional.

\section{Analisis Keunggulan Kompetitif Ubi Kayu Indonesia berdasarkan Konsep Privat Cost Ratio (PCR)}

Indikator yang digunakan dalam menentukan daya saing usahatani ubi kayu dalam penelitian ini menggunakan pendekatan keunggulan kompetitif dan komparatif. Keunggulan kompetitif diukur dengan menggunakan 
indikator nilai Privat Cost Ratio (PCR). Keunggulan kompetitif menunjukkan sejauh mana usahatani ubi kayu mampu membiayai faktor domestiknya pada harga privat atau aktual. Semakin kecil nilai PCR berarti komoditas tersebut semakin kompetitif. Keunggulan kompetitif mencerminakan efisiensi dalam penggunaan sumberdaya domestik, dengan kata lain, sejauh mana sumberdaya domestik dapat dihemat untuk menghasilkan satu satuan devisa. Untuk mengetahui nilai Privat Cost Ratio, diperlukan data berupa biaya tetap dan biaya variabel usahatani ubi kayu Indonesia seperti yang disajikan pada Tabel 3 berikut ini. Rasio biaya privat (Private Cost Ratio) merupakan rasio antara biaya privat input non tradable dengan selisih antara penerimaan privat dengan biaya privat input tradable privat. Nilai PCR menunjukkan kemampuan sistem untuk membayar biaya domestik pada harga privat atau aktualnya. Sehingga pada penelitian ini perlu dipisahkan antara biaya input tradable dan non tradable berdasarkan harga privat. Harga privat atau harga finansial adalah tingkat harga riil yang diterima petani dalam penjualan hasil produksinya. Input tradable adalah input yang diperdagangkan sehingga memiliki harga pasar internasional, yang termasuk dalam input tradeable adalah pupuk, benih, pestisida. Sedangkan input nontradable merupakan input yang tidak diperdagangkan secara internasional sehingga tidak memiliki harga pasar internasional yang termasuk dalam input nontradable adalah lahan, tenaga kerja, alat-alat pertanian, dan modal. Berdasarkan hasil analisis PCR pada Tabel 4, usahatani ubi kayu di Indonesia memiliki keunggulan kompetitif karena memiliki nilai Privat Cost Ratio (PCR) 0,36 atau kurang dari satu, yang berarti untuk mendapatkan nilai tambah output usahatani ubi

Tabel 3. Rata-Rata Biaya Tetap dan Biaya Variabel Usahatani Ubi Kayu Indonesia 2013

\begin{tabular}{lr}
\hline \multicolumn{1}{c}{ Uraian } & Rata-Rata (Rp) \\
\hline Biaya Produksi & \\
1. Pupuk urea & 749.927 .997 .683 \\
2. Pupuk Kandang & 182.324 .777 .562 \\
3. Pupuk Organik Pabrik & 172.936 .780 .886 \\
4. Pupuk Phonska & 600.621 .792 .643 \\
5. Pestisida & 99.809 .227 .825 \\
6. Tenaga kerja & 4.356 .648 .089 .323 \\
7. Sewa tanah & 2.449 .937 .317 .458 \\
8. Peralatan & 72.462 .981 .716 \\
9. Pajak (PBB) & 56.027 .811 .219 \\
Penerimaan & 20.825 .047 .154 .237 \\
\hline
\end{tabular}

Sumber : Data Primer yang diolah, 2016

Tabel 4. Penggolongan Penerimaan dan Biaya Usahatani Ubi Kayu Indonesia Berdasarkan Harga Privat tahun 2013

\begin{tabular}{lccccc}
\hline \multirow{2}{*}{ Uraian } & $\begin{array}{c}\text { Penerimaan } \\
\text { Output }\end{array}$ & \multicolumn{2}{c}{ Biaya Input } & \multirow{2}{*}{ Keuntungan } & \multirow{2}{*}{ PCR } \\
\cline { 3 - 4 } & $(\mathrm{A})$ & $(\mathrm{B})$ & $(\mathrm{C})$ & $(\mathrm{D}=\mathrm{A}-\mathrm{B}-\mathrm{C})$ & $(\mathrm{C} /(\mathrm{A}-\mathrm{B}))$ \\
\hline $\begin{array}{l}\text { Harga } \\
\begin{array}{l}\text { Privat } \\
(\text { (000Rp) }\end{array}\end{array}$ & 20.825 .047 .154 & 1.805 .620 .576 & 6.879 .048 .388 & 12.140 .378 .189 & 0,36 \\
\hline
\end{tabular}

Sumber: Data Primer yang diolah, 2016 
kayu sebesar satu satuan diperlukan tambahan biaya faktor domestik kurang dari satu satuan yaitu sebesar 0,36. Sedangkan keuntungan privat bernilai positif $(\mathrm{D}>0)$, hal tersebut menunjukkan bahwa indikasi dari hasil usahatani ubi kayu Indonesia supernormal dan harus mengarah pada ekspansi atau perluasan di masa mendatang, kecuali apabila daerah pertanian di Indonesia tidak dapat diperluas atau terdapat tanaman pengganti yang lebih menguntungkan secara privat.

Hasil analisis Privat Cost Ratio (PCR) yang menunjukkan bahwa komoditas ubi kayu Indonesia memiliki keunggulan kompetitif tersebut sesuai dengan penelitian terdahulu. Pada penelitian sebelumnya pada tahun 2011 yang meneliti daya saing ubi kayu, dilakukan analisis keunggulan kompetitif menggunakan Indeks Spesialisasi Perdagangan (ISP) untuk komoditas gaplek dan tapioka mempunyai daya saing kuat, atau Indonesia cenderung sebagai pengekspor dari komoditas tersebut. Sedangkan berdasarkan hasil analisis Acceleration Ratio (AR) secara rata-rata untuk komoditas gaplek, pati ubi kayu, dan tapioka mempunyai pangsa pasar ekspor yang kuat atau Indonesia dapat merebut pasar ekspor untuk komoditaskomoditas tersebut.

Nilai Privat Cost Ratio (PCR) yang kurang dari satu menunjukkan bahwa untuk menghasilkan satu-satuan nilai tambah output ubi kayu pada harga privat diperlukan kurang dari satu satuan biaya sumberdaya domestik. Dapat juga dikatakan bahwa, untuk menghemat satu-satuan devisa pada harga privat diperlukan korbanan lebih kecil dari satu-satuan biaya sumberdaya domestik.

Kondisi usahatani ubi kayu yang memiliki keunggulan kompetitif yang menjadi salah satu sebab mengapa usahatani ubi kayu selalu diusahakan dan berkembang di lapang. Saat ini petani menanam ubi kayu dikarenakan harga ubi kayu saat ini masih lebih baik dibandingkan dengan komoditas lain yang sering ditanam oleh petani seperti jagung dan kangkung. Selain itu, pengusahaan ubi kayu juga tidak memerlukan biaya pembenihan karena petani menyiapkan benih sendiri yang mudah didapat dari hasil tanam sebelumnya. Permintaan ubi kayu juga terus meningkat terutama untuk kebutuhan ekspor sehingga produksi ubi kayu Indonesia senantiasa ditingkatkan dengan serta mengoptimalkan sumberdaya domestiknya. Hasil penelitian ini menguatkan kembali hasil penelitian-penelitian sebelumnya mengenai daya saing ubi kayu yang menyatakan bahwa komoditas ubi kayu memiliki keunggulan kompetitif. Kondisi ini salah satunya dapat disebabkan oleh sistem usahatani yang digunakan di lokasi penelitian sudah mulai menerapkan teknologi yang diberikan oleh penyuluh pertanian. Sistem usatani ubi kayu jika dilakukan secara intensif dapat meningkatkan keunggulan kompetitif komoditas ubi kayu. Sistem usahatani ubi kayu secara intensif memiliki nilai keunggulan kompetitif yang lebih tinggi dibandingkan dengan sistem usahatani konvensional.

Penggunaan input yang tepat juga dapat membantu meningkatkan keunggulan kompetitif usahatani ubi kayu, artinya sistem usahatani yang efisien menjadi salah satu kunci untuk meningkatkan keunggulan kompetitif. Hal tersebut terbukti dengan tingginya keunggulan kompetitif usahatani ubi kayu di negara Thailand sebagai eksportir ubi kayu terbesar di dunia. Penggunaan input yang tepat menjadikan petani ubi kayu di negara Thailand mendapatkan keunggulan kompetitif dan keuntungan yang tinggi dalam kegiatan usahatani ubi kayu

\section{KESIMPULAN DAN SARAN}

\section{Kesimpulan}

1. Nilai Revealed Comparative Advantage (RCA) untuk komoditas ubi kayu Indonesia sebesar 0,7 atau di bawah satu, yang berarti pada periode tersebut ubi kayu Indonesia tidak memiliki keunggulan komparatif dibandingkan dengan negara lain dengan komoditas yang sama.

2. Nilai Privat Cost Ratio (PCR) untuk komoditas ubi kayu Indonesia sebesar 0,36 atau kurang dari satu, yang berarti pada periode tersebut ubi kayu Indonesia memiliki keunggulan kompetitif.

\section{Saran}

Untuk meningkatkan daya saing ubi kayu Indonesia, perlu adanya peningkatan kualitas dan kuantitas dari penjualan ubi kayu dengan mengembangkan dan meningkatkan ekspor ubi kayu dalam bentuk olahan (diversifikasi) sehinggadapat meningkatkan volume dan nilai ekspor ubi kayu. Penanganan pascapanen ubi 
kayu harus lebih ditingkatkan agar ubi kayu yang diekspor lebih banyak dalam bentuk olahan karena harganya yang lebih mahal dan daya tahannya selama pengiriman yang lebih kuat. Salah satu caranya dapatdilakukan dengan memberikan pelatihan dan bimbingan kepada petani danindustri pengolahan ubi kayu, penyediaan fasilitas, serta meningkatkan penelitian yang berkaitan dengan teknik dan proses pengolahan ubi kayu.

Dalam mengatasi masalah permodalan dan pembiayaan usaha tanaman ubi kayu, pemerintah harus menjalin kerjasama dan melakukan pendekatan pada pihak perbankan ataupun memberikan bantuan kepada para kelompok tani agar dapat mulai memberikan bantuan modal khusus terhadap sektor ubi kayu. Disamping mendapat bantuan modal, petani ubi kayu juga harus mendapat pendampingan dan bimbingan dari pihak-pihak yang mampu seperti tenaga ahli dari Departemen Pertanian maupun Lembaga pendidikan agar ketersediaan ubi kayu yang ada menjadi semakin berkualitas bagi konsumen dalam negeri dan layak untuk diekspor.

Infrastruktur Indonesia diharapkan dapat ditingkatkan kuantitas dan kualitasnya sesuai kebutuhan dalam pengelolaan agribisnis ubikayu, karena untuk kebutuhan ekspor, infrastruktur adalah bagian yang sangat penting yang harus mendapat perhatian mendalam khususnya dalam pelabuhan dan jalan untuk sarana transportasi.

\section{DAFTAR PUSTAKA}

Anwar MF. 2014. Analisis Daya Saing Industri Furniture Rotan Kabupaten Sukoharjo. Jurnal Agrista Edisi 4 Vol 2

Arifin dan Junaiyah HM 2010. Keutuhan Wacana. Grasindo. Jakarta.

Asriani PS 2010. Perdagangan Ubi kayu Indonesia di Pasar Dunia. Jurnal AGRISEP Vol 9 No. 2: 184-196

Basri F. 2010. Dasar-Dasar Ekonomi Internasional: Pengenalan dan Aplikasi Metode Kuantitatif. Kencana. Jakarta.

[BPS]. Badan Pusat Statistik. 2015. Kontribusi Tanaman Pangan Terhadap PDB Sektor Pertanian Tahun 2004-2013. Badan Pusat Statistik. Jakarta

[BPS]. Badan Pusat Statistik. 2015. Luas Areal dan Produksi Ubi kayu Indonesia dan Tiga Propinsi Terbesar Menurut Pengusahaan Tahun 2013. Badan Pusat Statistik. Jakarta

Mankiw, N. G. 2008. Makro Ekonomi. Erlangga. Jakarta

Monke EA, Pearson SR. 1989. The Policy Analysis Matrix for Agricultural Development. Cornel University Press. London.

Pusat Data dan Sistem Informasi Pertanian. 2015. Outlook Komoditas Pertanian Tanaman Pangan Ubi Kayu. Kementerian Pertanian. Jakarta 